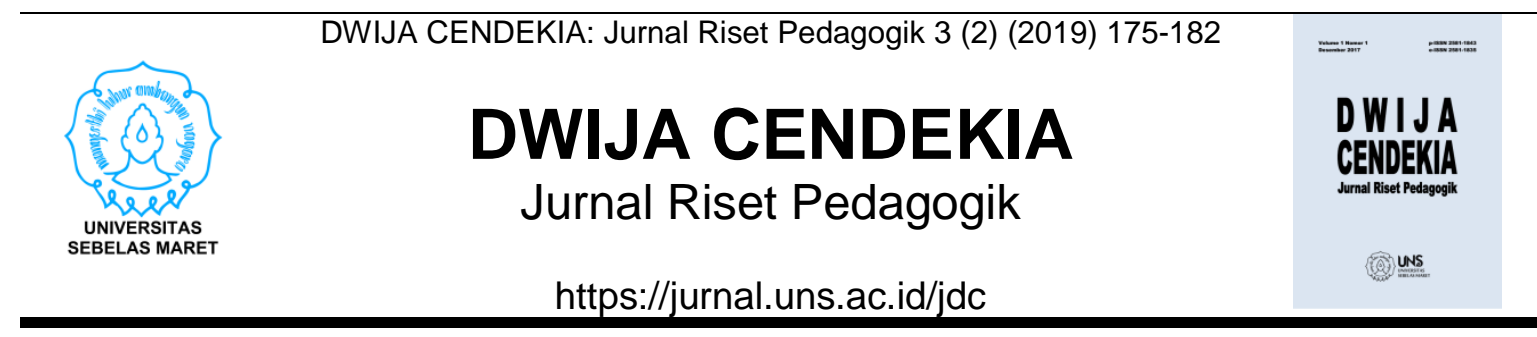

\title{
Implementasi Cooperative Learning dengan Menggunakan Strategi Rally Coach untuk Mengembangkan Keterampilan Komunikasi Matematis
}

\author{
Joko Krismanto Harianja \\ Universitas Pelita Harapan \\ joko.harianja@outlook.co.id
}

\section{Sejarah Artikel}

diterima 28/09/2019

diterbitkan 13/12/2019

\begin{abstract}
The purpose of this research was to develop students' mathematical communication skills with rally coach strategy.. Based on the result of this research, it is known that by using rally coach strategy, students are able to translate mathematical statements into mathematical sentences using mathematical symbols such as mathematical equations and algebraic expressions even communicating them verbally. The research methodology used in this research is CAR (Classroom Action Research) with collecting data method by observation and validity test using triangulation. The results of this research obtained in this study is to achieve an increase in mathematical communication skills of students through the percentage of each indicator in the first cycle and second cycle along with the increase of students' achievement.

Keywords: cooperative learning, rally coach, mathematical communication
\end{abstract}

\section{Abstrak}

Tujuan dari penelitian ini untuk mengembangkan keterampilan komunikasi matematis siswa dengan strategi rally coach. Berdasarkan hasil penelitian diketahui bahwa dengan menggunakan strategi rally coach, siswa mampu menerjermahkan pernyataan-pernyataan matematika ke dalam bentuk kalimat matematika dengan menggunakan simbol matematika seperti persamaan matematika maupun ekspresi aljabar bahkan mengkomunikasikannya secara lisan. Metode penelitian yang digunakan dalam penelitian ini adalah PTK (Penelitian Tindakan Kelas) dengan metode pengambilan data secara observasi dan uji validitas menggunakan triangulasi. Hasil penelitian yang telah diperoleh dalam penelitian ini adalah dengan tercapainya peningkatan keterampilan komunikasi matematis siswa melalui persentasi pada setiap indikator pada siklus I dan siklus II serta hasil belajar siswa yang meningkat.

Kata kunci: cooperative learning, rally coach, komunikasi matematis

e-ISSN 2581-1835

p-ISSN 2581-1843 


\section{PENDAHULUAN}

Model pembelajaran dengan menggunakan konsep cooperative learning sudah sejak lama dicetuskan oleh para ahli di bidang pendidikan dan masih secara berkesinambungan diteliti sampai saat ini (Patesan, 2016). Istilah cooperative learning mengacu kepada model pembelajaran yang mengandalkan bentuk kerjasama di dalam belajar (Kagan, 1994). Hal ini mengutamakan metode belajar siswa secara kooperatif (bekerjasama) dengan siswa yang lain di dalam suatu kelompok, di mana setiap siswa dalam kelompok tersebut memiliki kesempatan yang sama untuk saling berkomunikasi dan berdikusi dalam memecahkan maupun menyelesaikan suatu masalah. Dalam situasi ini, siswa juga berkesempatan untuk saling bertukar pikiran dan mengutarakan pendapat mereka.

Ada tiga konsep sentral yang menjadi karakteristk metode pembelajaran cooperative learning sebagaimana dikemukakan oleh Slavin (Lie, Anita., 2005). Pertama, penghargaan kelompok yang diperoleh jika kelompok mencapai skor di atas criteria yang ditentukan. Sehingga keberhasilan kelompok didasarkan pada penampilan individu sebagai anggota kelompok dalam menciptakan hubungan antar personal yang saling mendukung, saling membantu, dan saling peduli. Kedua, keberhasilan kelompok tergantung pada belajar individual dari semua anggota kelompok. Tanggung jawab ini menitiberatkkan pada aktivitas anggota kelompok saling membantu dalam belajar. Ketiga, cooperative learning menggunakan metode scoring yang mencakup nilai perkembangan berdasarkan peningkatan prestasi yang diperoleh siswa dari terdahulu. Dengan menggunakan metode skoring ini setiap siswa yang berprestasi rendah, sedang dan tinggi sama-sama memperoleh kesempatan untuk berhasil dan melakukan yang terbaik bagi kelompok.

Strategi rally couch adalah salah satu strategi pembelajaran dalam cooperative learning yang secara teknis terdiri dari dua orang siswa dalam satu kelompok, biasanya siswa diberikan penamaan partner $A$ dan partner $B$ yang akan mendapat kesempatan secara bergantian untuk menyelesaikan suatu persoalan atau pertanyaan (Kagan, 1994).

Strategi Rally coach adalah sebuah startegi yang sangat tepat untuk diimplementasikan dalam pelajaran matematika khususnya ketika sedang menjawab pertanyaan. Strategi ini mendorong siswa untuk saling membantu satu dengan yang lain dalam menjawab pertanyaan. Dalam implementasinya, siswa diharuskan untuk saling berkomunikasi dan memperhatikan dengan teliti proses yang dilakukan ketika sedang menjawab pertanyaan. Ketika siswa sedang menjawab persoalan, tidak lain membutuhkan proses berpikir yang sedemikian rupa sehingga dapat dituangkan dalam tulisan dan kemudian dikomunikasikan kepada orang lain.

Di dalam proses kegiatan belajar dan mengajar, komunikasi adalah aspek yang sangat penting. Secara umum kita mengetahui dengan jelas bahwa komunikasi adalah kebutuhan dasar dalam kehidupan manusia 
sebagai mahluk sosial. Dengan berkomunikasi setiap orang dapat berinteraksi, saling bertukar pikiran, ide atau gagasan dengan sesamanya. Saat sedang berkomunikasi, interaksi dapat dilakukan melalui simbol-simbol verbal maupun nonverbal (Yeni Yuniarti, 2014).

Matematika memiliki peran
sebagai bahasa simbolik yang
memungkinkan
terwujudnya
komunikasi secara cermat dan tepat.
Matematika tidak hanya sekedar ilmu
bantu berpikir tetapi matematika
sebagai wahana komunikasi antar
siswa dan guru dengan siswa. Semua
orang diharapkan dapat
menggunakan bahasa matematika
untuk mengkomunikasikan informasi
maupun ide-ide yang diperolehnya.

Komunikasi matematika merupakan alat bantu dalam transmisi pengetahuan matematika atau sebagai pondasi dalam membangun pengetahuan matematika (Guerreiro, 2008). Kemampuan komunikasi matematika dapat diartikan sebagai suatu kemampuan siswa dalam menyampaikan sesuatu yang diketahuinya melalui peristiwa berupa dialog atau saling hubungan yang terjadi di lingkungan kelas, di mana terjadi pengalihan pesan. Pesan yang dikirimkan berisi tentang materi matematika yang dipelajari siswa, misalnya berupa konsep, rumus atau strategi penyelesaian suatu masalah. Pihak yang terlibat dalam peristiwa komunikasi di dalam kelas adalah guru dan siswa. Cara pengalihan pesannya dapat secara lisan maupun tertulis (Herdian, 2010).

National Council of Teacher of Mathematics (NCTM: 2000) menyatakan bahwa kemampuan komunikasi matematis merupakan salah satu aspek yang termasuk di dalam kemampuan berpikir secara matematis. Melalui pembelajaran matematika, siswa diharapkan untuk memiliki dan mengembangkan kemampuan komunikasi matematis melalui mengkomunikasikan gagasan dengan simbol, tabel, diagram atau media lain untuk memperjelas keadaan atau masalah.

Berikut ini adalah uraian mengenai indikator kemampuan siswa dalam komunikasi matematis pada pembelajaran menurut NCTM (NCTM, 2000), yaitu kemampuan mengekspresikann ide-ide matematika melalui lisan, tertulis, dan mendemonstrasikannya serta menggambarkannya secara visual; kemampuan memahami, menginterpretasikan dan mengevaluasi ide-ide matematika baik secara lisan maupun bentuk visual lainnya; kemampuan dalam menggunakan istilahi-istilah, notasinotasi matematika dan strukturstrukturnya untuk menyajikan ide, menggambarkan hubungan-hubungan dan model-model situasi.

Menurut Ansari, indikator yang menunjukkan kemampuan komunikasi matematis siswa dapat dikelompokkan menjadi tiga bagian, yaitu (Dewi, 2017), yaitu menggambar, yaitu dengan merefleksikan benda-benda nyata, gambar dan diagram ke dalam ide-ide matematika. Atau sebaliknya, dari ide-ide matematika ke dalam bentuk gambar atau diagram; ekpresi matematika dengan menyatakan peristiwa sehari-hari dalam bahasa atau simbol matematika, dan menulis, yaitu memberikan jawaban dengan menggunakan bahasa sendiri, membuat model situasi atau persoalan menggunakan bahasa lisan, tulisan, grafik, ekspresi aljabar, 
menjelaskan, membuat pertanyaan tentang matematika yang telah dipelajari, mendengarkan, mendiskusikan, membuat konjektur, menyusun argumen dan generalisasi.

Berdasarkan kutipan di atas dapat dilihat bahwa kemampuan komunikasi matematika merupakan kemampuan yang menyatakan ide matematika melalui lisan dan tulisan. Kemampuan komunikasi matematika lisan siswa dapat diukur saat siswa tersebut

mengemukakan pengetahuan matematika mereka. Kemampuan komunikasi matematika tulisan dapat diukur melalui tulisan siswa mengenai matematika. Dengan kata lain, sebagai kesimpulan kutipan yang telah diuraikan di atas, kemampuan komunikasi matematis merupakan kemampuan siswa untuk mengungkapkan pemikiran matematisnya dalam bentuk lian, tulisan maupun gambar dengan menggunakan bahasa yang baik dan tepat, serta dapat memahami representasi matematis dengan baik.

\section{METODOLOGI}

Pendekatan penelitian yang digunakan oleh penulis dalam penelitian ini merupakan penelitian tindakan kelas (PTK). Penelitian tindakan kelas adalah pengembangan dari penelitian yang dikembangkan dengan tujuan untuk mencari penyelesaian terhadap masalah sosial. Penelitian tindakan yang diawali dengan kajian terhadap suatu persoalan yang sistematis (Suharsimi, 2006). Hasil kajian ini akan dijadikan dasar untuk menyusun suatu rencana kerja (tindakan) sebagai suatu upaya untuk mengatasi persoalan tersebut. Kegiatan berikutnya adalah pelaksanaan tindakan dilanjutkan dengan observasi dan evaluasi. Hasil observasi dan evaluasi digunakan sebagai masukkan melakukan refleksi atas apa yang terjadi pada saat pelaksanaan tindakan. Hasil refleksi kemudian dijadikan landasan untuk menentukan perbaikan serta penyempurnaan tindakan selanjutnya.

Analisa data dalam penelitian ini dilakukan dengan cara mengumpulkan data di tempat penelitian. Penyajian data seperti mengumpulkan informasi mengenai data yang kemudian disusun secara berurutan dan memverifikasi data yang dilakukan pada setiap tindakan yang pada akhirnya dapat digunakan sebagai bahan kesimpulan. Pada analisa hasil yang ditekankan pada siswa yaitu berupa indikator kemampuan komunikasi matematis

Uji validitas yang digunakan dalam penelitian ini adalah dengan menggunakan triangulasi. Triangulasi adalah teknik pemeriksaan keabsahan suatu data dengan memanfaatkan sesuatu yang lain untuk keperluan pengecekan atau sebagai pembanding terhadap data tersebut. Dalam penelitian ini triangulasi yang digunakan adalah triangulasi sumber dan triangulasi metode serta dengan melakukan observasi secara terus menerus selama proses pembelajaran berlangsung.

Ada empat tahapan yang harus dikerjakan dalam penelitian tindakan kelas menggunakan model spiral Kemmis dan Mctaggart. Tahapan-tahapan tersebut adalah tahap perencanaan (plan), tahap tindakan (act), tahap pengamatan (observe) dan tahap refleksi (reflect) (McTaggart, 1993). Di dalam 
penelitian ini dilakukan beberapa siklus untuk mengembangkan kemampuan komunikasi matematis siswa dalam pembelajaran matematika menggunakan metode pembelajaran cooperative learning dengan strategi rally coach.
Siklus dapat dihentikan apabila pembelajaran matematika menggunakan strategi rally coach telah berhasil mencapai indikator komunikasi matematika

\section{PEMBAHASAN}

Berdasarkan

kegiatan pembelajaran yang telah dilakukan menggunakan strategi rally coach di dalam kelas secara menyeluruh pada siklus I dan siklus II, diperoleh adanya peningkatan keterampilan komunikasi matematis siswa pada topik materi "expansion and simplification of algebraic expressions" serta "algebraic manipulation." Data yang merupakan hasil penelitian yang telah diperoleh dapat dilihat pada tabel 1 .

Tabel 1. Data Peningkatan Kemampuan Komunikasi Matematis Siswa

\begin{tabular}{|c|c|c|c|c|}
\hline No. & Indikator & $\begin{array}{l}\text { Sebelum } \\
\text { Tindakan }\end{array}$ & Siklus I & Siklus II \\
\hline 1. & $\begin{array}{lr}\text { Siswa } & \text { mampu } \\
\text { mendeskripsikan } & \text { atau } \\
\text { menggambarkan } & \text { situasi } \\
\text { masalah dan menyatakan } \\
\text { solusi dari suatu persolan } \\
\text { dengan menggunakan } \\
\text { gambar, bagan, tabel dan } \\
\text { secara aljabar. }\end{array}$ & $\begin{array}{c}7 \text { siswa } \\
(36.84 \%)\end{array}$ & $\begin{array}{l}11 \text { siswa } \\
(57.89 \%)\end{array}$ & $\begin{array}{l}17 \text { siswa } \\
(89.47 \%)\end{array}$ \\
\hline 2. & $\begin{array}{l}\text { Siswa mampu mengemukakan } \\
\text { dan menjelaskan ide, solusi } \\
\text { serta relasi matematika secara } \\
\text { tepat. }\end{array}$ & $\begin{array}{c}8 \text { siswa } \\
(42.10 \%)\end{array}$ & $\begin{array}{l}12 \text { siswa } \\
(63.15 \%)\end{array}$ & $\begin{array}{l}15 \text { siswa } \\
(78.94 \%)\end{array}$ \\
\hline 3. & $\begin{array}{l}\text { Siswa mampu menggunakan } \\
\text { bahasa matematika secara } \\
\text { tepat. }\end{array}$ & $\begin{array}{c}7 \text { siswa } \\
(36.84 \%)\end{array}$ & $\begin{array}{l}12 \text { siswa } \\
(63.15 \%)\end{array}$ & $\begin{array}{l}16 \text { siswa } \\
(84.21 \%)\end{array}$ \\
\hline 4 & $\begin{array}{l}\text { Siswa mampu menjelaskan } \\
\text { secara lisan proses yang } \\
\text { dicapai untuk solusi dari situasi } \\
\text { masalah. }\end{array}$ & $\begin{array}{c}6 \text { siswa } \\
(31.57 \%)\end{array}$ & $\begin{array}{l}13 \text { siswa } \\
(68.42 \%)\end{array}$ & $\begin{array}{l}15 \text { siswa } \\
(78.94 \%)\end{array}$ \\
\hline
\end{tabular}

Berdasarkan pengamatan yang telah dilakukan oleh penulis dalam penelitian ini pada siklus I di mana terlihat kemampuan komunikasi matematis siswa dalam pembelajaran matematika telah mengalami peningkatan yang baik dan cukup signifikan indikator keberhasilan yang diinginkan oleh peneliti meskipun belum begitu berarti. Hal ini dapat dilihat dari jumlah siswa yang telah memiliki kemampuan menjelaskan secara lisan proses yang dicapai untuk solusi dari masalah yang sedang dipecahkan yang mengalami kenaikan jumlah dari 7 siswa (36.84\%) menjadi 12 siswa (63.15\%). Sebagai salah satu faktor yang mengakibatkan hal ini terjadi karena siswa belum terbiasa dengan pembelajaran dengan strategi rally coach. Namun, meskipun demikian tetap ada peningkatan yang baik. 
Hasil penelitian pada siklus I menjadi refleksi bagi penulis untuk melakukan perencanaan perbaikan yang akan dilakukan pada tindakan siklus II. Dari hasil penelitian yang telah diperoleh pada tindakan siklus II terlihat adanya peningkatan yang sangat signifikan terhadap keterampilan komunikasi matematis siswa. Presentasi indikator kemampuan komunikasi matematis siswa mengalami peningkatan pada setiap siklus penelitian.
Untuk mendukung hasil penelitian yang telah diperoleh dalam pengembangan keterampilan komunikasi matematis siswa, penulis memberikan data hasil belajar siswa kelas 7 sebelum dan setelah melakukan kegiatan pembelajaran menggunakan metode pembelajaran cooperative learning dengan strategi rally coach sebagai berikut :

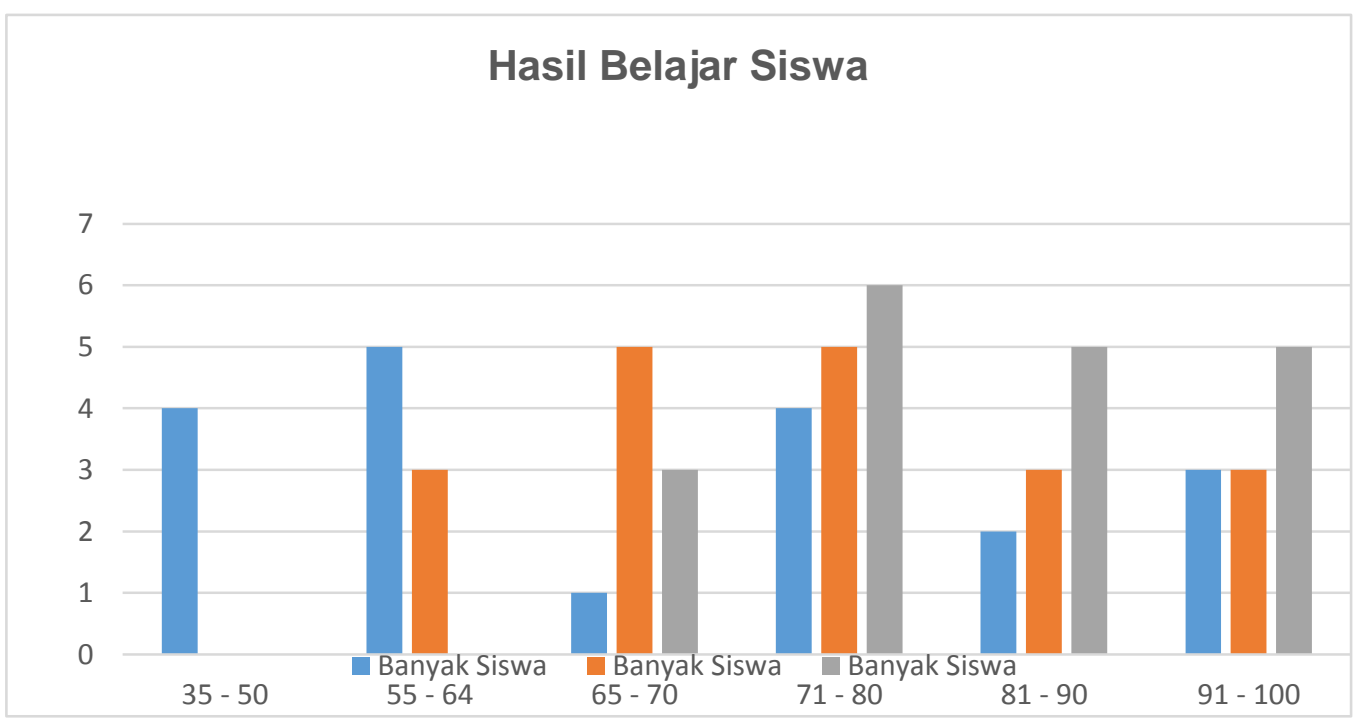

Gambar 1. Grafik Data Hasil Belajar Siswa

Peningkatan nilai hasil belajar dengan dengan strategi rally coach sejalan dengan pengembangan keterampilan komunikasi matematis siswa. Meskipun yang menjadi tujuan utama dalam penelitian ini adalah pengembangan keterampilan komunikasi matematis siswa dalam pelajaran matematika, tidak menutup kemungkinan bahwa keberhasilan dalam mencapai tujuan tersebut dihubungkan dengan hasil pembelajaran siswa secara akademik yang diperoleh melalui tes yang diberikan. Dengan kata lain, meningkatnya keterampilan komunikasi siswa secara matematis sejalan dengan meningkatnya hasil belajar siswa.

Hasil penelitian yang telah diuraikan di atas sesuai dengan pendapat Sudjana (Sudjana, 2013) yang menyatakan bahwa hasil proses belajar siswa dapat ditunjukkan dalam berbagai bentuk seperti perkembangan pengetahuan, pemahaman, sikap dan tingkah laku, keterampilan, kecakapan dan kemampuan, daya reaksi, daya 
penerimaan serta aspek-aspek yang terdapat pada individu. Sejalan dengan Sudjana, Hamalik (Hamalik, 2008) menyatakan bahwa hasil belajar adalah sebagai perubahan perilaku pada diri seseorang yang bisa diamati dan diukur dalam bentuk pengetahuan, sikap dan keterampilan. Perubahan itu bisa diartikan sebagai sebuah peningkatan yang lebih baik terhadap pengetahuan sebelumnya. Pada akhir setiap proses pembelajaran, siswa diharapkan untuk memiliki kemampuan mendemostrasikan setiap keterampilan yang telah diterima dan dikembangkan dalam proses pembelajaran di dalam kelas.

\section{SIMPULAN}

Melalui penelitian yang telah dilakukan dan observasi langsung di dalam kelas, sebagai hasil yang implementasi strategi rally coach, siswa mampu memahami konsep matematika secara luas melalui aktif berpartispasi untuk saling berdiskusi dan melalui kesempatan yang diberikan untuk menuangkan hasil pemahaman mereka terhadap persoalan yang diberikan, mengkomunikasikannya baik secara lisan maupun tulisan. Selama proses ini berlangsung, siswa berusaha untuk menjelaskan kepada siswa lain langkah-langkah yang harus ditempuh untuk memecahkan persoalan matematika yang diberikan.

Dari setiap kegiatan pembelajaran matematika siswa kelas 7B Sekolah Bogor Raya (SBR) menggunakan strategi rally coach, dapat dilihat dan diketahui bahwa siswa dapat mencapai seluruh indikator kemampuan matematis baik secara lisan dan tulisan, kemampuan matematis dengan menuliskan serta menjelaskan ide atau solusi dari suatu permasalahan dengan menggunakan bahasa sendiri dan ekpresi matematika dalam bentuk pernyataan aljabar telah tercapai dengan baik. Hal ini dapat dilihat dari hasil yang telah diuraikan pada bagian pembahasan di mana terlihat dengan jelas adanya peningkatan presentasi masingmasing indikator dari sebelum dilakukannya tindakan dan dilakukannya tindakan pada siklus I dan siklus II. Melalui metode pembelajaran cooperative learning menggunakan strategi rally coach, pembelajaran matematika di dalam kelas mejadi lebih menarik dan interaktif sehingga sudut pandang siswa terhadap pembelajaran matematika menjadi lebih positif sehingga merangsang siswa untuk menyukai pembelajaran matematika. Selain itu, bukan hanya keterampilan komunikasi matematis yang dapat dikembangkan, keterampilan lain seperti berpikir secara kritis, berpikir secara sistematis dan interaksi sosial dapat dikembangkan dengan menggunakan strategi rally coach. Strategi rally coach telah terbukti dengan baik dapat membantu siswa dalam mengembangkan keterampilanketerampilan tersebut. 


\section{DAFTAR PUSTAKA}

Dewi, Riska. (2017). Pengembangan Instrumen Tes Untuk Mengukur Kemampuan Komunikasi Matematis Siswa SMP Negeri 17 Makasar. Universitas Islam Negeri Alaudin Makassar Repositori

Guerreriro, A. (2008). Communication in Mathematics Teaching and Learning: Practices in Primary Education. New York: Springer

Hamalik, Oemar. (2008). Kurikulum dan Pembelajaran. Jakarta: Sinar Grafika

Herdian. (2010). Kemampuan Pemahaman Matematika. Jurnal Pendidikan Matematika

Isjoni. (2009). Cooperative Learning: Efektivitas Pembelajaran Kelompok. Bandung: Alfabeta

Kagan, Spencer. (1994). Kagan Cooperative Learning. Sydney: Kagan Publisher

Lie, Anita. (2005). Cooperative Learning dan Mempraktekkan Cooperative Learning di Ruang Kelas. Jakarta: Grasindo

Mctaggart, Robin. (1993). Action Research, A short Modern Histroy. Australia: Deakin University

National Council of Teachers or Mathematics. (2000). Princples and Standards for School Mathematics. Virginia: National Council of Teachers of Mathematics Inc

Patesan, Marioara. (2016). The Benefits of Cooperative learning. De Gruyter: International Conference Knowledge-Based Organization

Sudjana, Nana. (2013). Dasar-Dasar Proses Belajar Mengajar. Bandung: Sinar Baru Algensindo.
Suharsimi, Arikunto, dkk. (2006). Penelitian Tindakan Kelas. Jakarta: Bina Aksara Yuniarti, Yeni. (2014). Pengembangan Kemampuan Komunikasi Matematis dalam Pembelajaran Matematika di Sekolah Dasar. Eduhumaniora JournaL. 